\title{
Effects of biochar derived from maize stover and rice straw on the germination of their seeds
}

\author{
Alie Kamara ${ }^{1}$, Abibatu Kamara ${ }^{2}$, Mary Mankutu Mansaray ${ }^{2}$, Patrick Andrew Sawyerr ${ }^{1}$ \\ ${ }^{1}$ Soil Science Department, School of Agriculture, Njala Campus, Njala University, Sierra Leone \\ ${ }^{2}$ Extension Division, Ministry of Agriculture, Forestry and Food Security, Sierra Leone \\ Email address: \\ aliekamara@njala.edu.sl (Alie K.)
}

\section{To cite this article:}

Alie Kamara, Abibatu Kamara, Mary Mankutu Mansaray, Patrick Andrew Sawyerr. Effects of Biochar Derived from Maize Stover and Rice Straw on the Germination of their Seeds. American Journal of Agriculture and Forestry. Vol. 2, No. 6, 2014, pp. 246-249.

doi: $10.11648 /$ j.ajaf.20140206.12

\begin{abstract}
Although there has been an increased focus on the use of biochar for improving soil fertility and mitigating climate change, some biochars have been reported to contain substances that affect germination and seedling growth negatively. It is therefore necessary to evaluate any biochar material for its effect on seed germination before large scale applications. This study was therefore undertaken to assess the effects of (i) biochar derived from maize stover on maize seed germination and (ii) biochar derived from rice straw on rice seed germination. Seeds of maize (Zea maize L.) and rice (Oryza sativa) were sown separately to soils treated with increasing levels of biochar derived from maize and rice residues respectively. The experiment was conducted using a completely randomized design involving five biochar treatments: $0 \mathrm{~g}$ (control), $1.25 \mathrm{~g}, 2.50 \mathrm{~g}, 3.75 \mathrm{~g}$ and $5.00 \mathrm{~g}$ each mixed with $300 \mathrm{~g}$ of a fine sandy loam soil in Sierra Leone. Results of the germination test showed that most of the maize seeds $(>80 \%)$ germinated by day 3 and there was no significant difference in the number of maize seeds germinated on day 7 . On the other hand, few rice seeds germinated on day3 (35\%) and was significantly greater than the number of the rice seeds $(>90 \%)$ germinated on day 7. However, even though the number of maize or rice seeds germinated on biochar treated soils was higher than the control, the difference was not significant. Also, no significant differences in root lengths were observed between the control and biochar treatments at day 7 for both plants. However, maize shoot length differed significantly from the control whereas rice shoot length did not. The results showed that sowing seeds of maize and rice on soils treated with biochar derived from their crop residues had no adverse effect on germination. These findings hold great potential for improved and sustainable maize and rice cultivation in Sierra Leone.
\end{abstract}

Keywords: Biochar, Rice Straw, Maize Stover, Germination

\section{Introduction}

Crop production on Sierra Leone soils faces challenges due to soil acidity, low water and nutrient retention. For such soils, maintenance or improvement of soil organic matter content is the key to sustainable cropping. One important approach to soil organic matter management is by addition of crop residues. Crop residues when incorporated or left on the soil surface eventually decompose releasing nutrients and carbon dioxide back into the atmosphere [1]. Consequently the benefits of adding organic matter to soil, such as, improved water and nutrient retention are basically short-lived and continuous additions are necessary to maintain productivity.

A more lasting approach to improving soil productivity is by applying carbon into the soil in the form of biochar.
Biochar is a stable form of carbon produced from heating natural organic materials (such as crop residues and other biomass wastes) in little or no oxygen environment in a process known as pyrolysis. Biochar refers to the charred organic matter or charcoal, produced with the intent to deliberately apply to soils to sequester carbon and improve soil properties [2]. Additions of biochar to soil have been reported to increase $\mathrm{pH}$ and cation exchange capacity $[3,4,5]$ as well as nutrient availability $[6,7]$.

During pyrolysis, plant biomass undergoes a series of physical and chemical changes. Physical changes in plant biomass during pyrolysis basically involve mass loss and volume reduction without significant changes in the original structure [8]. The shrinkage in volume and mass loss are due to loss of volatile compounds in the original plant material [9] and result in concentration of nutrients into the charred 
remains or biochar fraction. Thus converting crop residues into biochar and and applying to soils, is a convenient way of returning nutrients to the soil. Furthermore, biochar is resistance to microbial decomposition [10] and therefore soil biochar applications offer the potential to sequester carbon in agricultural lands $[11,12,13]$ thereby mitigating climate change.

Generally, biochar as a renewable bio-resource has the potential of positively impacting soil and crop productivity. However some biochars have been reported to contain substances that affect germination and seedling growth negatively [14]. It is therefore necessary to evaluate any biochar material for its effect on seed germination before large scale applications. This study was therefore undertaken to assess the effects of (i) maize stover biochar on maize seed germination and (ii) rice straw biochar on rice seed germination using a soil-based assay.

\section{Methodology}

\subsection{Description of the Study Area}

The experiment was conducted in Njala Campus, Njala University in the Moyamba District in Southern Sierra Leone, West Africa. Njala is about $255 \mathrm{~km}$ from Freetown, the capital city of Sierra Leone and is located at an elevation of $128 \mathrm{~m}$ above sea level (altitude), on Latitude $8^{0} \mathrm{~N}$ and Longitude $12^{0} \mathrm{~W}$. The climate is tropical and is characterized by two main seasons; a rainy season (April to October) and a dry season (November to March). The average annual rainfall is about $2500 \mathrm{~mm}$ and the mean annual temperature ranges from a minimum of $28^{\circ} \mathrm{C}$ to a maximum of $33^{\circ} \mathrm{C}$.

\subsection{Biochar Production and Processing}

Maize stover and rice straw were collected from farms in Mosongo, one of the villages around Njala University Campus. Each crop residue was thoroughly dried in the sun and converted to biochar using the Elsa stove designed for the BeBi Project in Njala University. [The Elsa stove is a low-tech Top-Lit-Up-Draft (TLUD) bioenergy stove designed for use in domestic cooking and production of biochar for application to soils under the Project Agricultural and Environmental Benefits of Biochar Use in ACP Countries - 'BeBi']. The charred material (biochar) was quenched with water (by sprinkling water on the hot char) and dried in the sun for a few days. The dry biochar was crushed and sieved through a $2 \mathrm{~mm}$ sieve and stored.

\subsection{Properties of Biochar and Soil Used in the Study}

The soil used in this study had the following characteristics: pH 4.7 (1:1 soil:water ratio), organic carbon $2.1 \mathrm{~g} / \mathrm{kg}$ soil (Walkley-Black), available phosphorus $5.6 \mathrm{mg} / \mathrm{kg}$ soil (Bray \& Kurtz 1), cation exchange capacity $6.2 \mathrm{cmol}(+) / \mathrm{kg}$ soil (neutral $\mathrm{M} \mathrm{NH}_{4} \mathrm{OAc}$ ), exchangeable cations $0.28,0.19,0.12$ and $0.02 \mathrm{cmol}+/ \mathrm{kg}$ soil $\mathrm{Ca}, \mathrm{Mg}, \mathrm{K}$ and $\mathrm{Na}$ respectively, and particle size ( $70 \%$ sand, $16 \%$ silt and $14 \%$ clay). Maize stover biochar had the following characteristics: $\mathrm{pH} 8.4$, electrical conductivity (1:5 biochar:water) $3.98 \mathrm{dSm}^{-1}$. Rice straw, on the other hand, had the following characteristics: $\mathrm{pH} 8.8$, electrical conductivity (1:5) $2.82 \mathrm{dSm}^{-1}$.

\subsection{Germination Test}

This study involved five biochar application rates (treatments) in four replications in a completely randomized design (CRD). Each of five biochar treatments $(0 \mathrm{~g}, 1.25 \mathrm{~g}$, $2.50 \mathrm{~g}, 3.75 \mathrm{~g}$ and $5.00 \mathrm{~g}$ ) was mixed thoroughly with $300 \mathrm{~g}$ of a fine sandy loam soil (Mokonde Series) located in the Njala area. The test was conducted for seven days. The soil-biochar mixture was placed separately in five small cylindrical containers of dimensions $10 \mathrm{~cm}$ diameter and $5 \mathrm{~cm}$ height. The soil in each container was moistened with $140 \mathrm{~g}$ of water (47\%w/w moisture content) and four seeds of maize (Zea maize L.) or rice (Oryza sativa) were planted to $2 \mathrm{~cm}$ depth in each container. After planting, the pots were covered with a transparent plastic sheet for 48 hours to minimise moisture loss and allowing access to sunlight.

The number of plants that germinated on day 3 and 7 was recorded for each treatment. On day 7 the germination test was terminated and data collected on total plant length, length above ground and length below ground

\subsection{Statistical Analysis}

Statistical differences among treatments were determined by Analysis of Variance (ANOVA) for Completely Randomized Designs (CRD) and LSD $(\mathrm{P}<0.05)$ in the GenStat $12^{\text {th }}$ Edition computer software.

\section{Results}

\subsection{Effect of Maize Stover Biochar on the Germination of Maize Seeds}

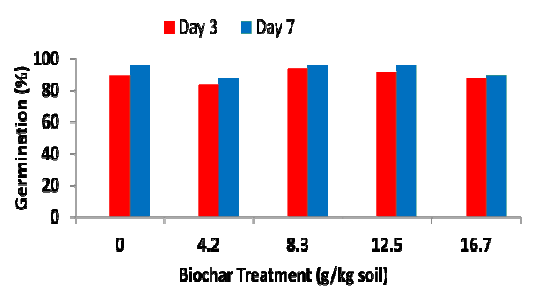

Figure 1. Percentage germination of maize seeds after three and seven days on soil mixed with biochar derived from maize stover

The percentage germination of maize seeds as influenced by increasing levels of application of biochar derived from maize stover on a sandy loam are shown on Fig.2. The pattern of maize seed germination was similar at both 3 and 7 days after planting (DAP). At biochar application rate of $4.2 \mathrm{~g} / \mathrm{kg}$ soil, there was a slight decrease in germination compared with the control but increased slightly again at $8.3 \mathrm{~g} / \mathrm{kg}$ soil biochar application, then decreased slightly again at higher application rates. These variations, however, were not significantly different $(\mathrm{p}<0.05)$ among each other at both 3 and 7 DAP. At day 3 most of the maize seeds $(>80 \%)$ have germinated and did not differ significantly $(p<0.05)$ 
from the number of seeds germinated at day 7 . Thus the presence of biochar neither improved nor adversely affected maize germination.

\subsection{Effect of Rice Straw Biochar on the Germination of Rice Seeds}

Fig. 2 shows the percentage germination of rice seeds with increasing levels of application of rice straw biochar on a fine sandy loam. At 3 DAP percent rice seed germination was less than the control for most biochar application rates except at $16.7 \mathrm{~g} / \mathrm{kg}$ soil. On the other hand, at 7 DAP there was a slight decrease in percent rice seed germination from the control at biochar application rate of $4.2 \mathrm{~g} / \mathrm{kg}$ soil but increased again slightly above the control at higher biochar application rates. Nonetheless, there was no significant difference $(\mathrm{p}<0.05)$ in germination between the control and biochar treatments at 7 DAP. There was also no significant difference among treatments at 3 DAP. On the other hand, the percentage germination of rice seed increased significantly between 3 and 7 DAP.

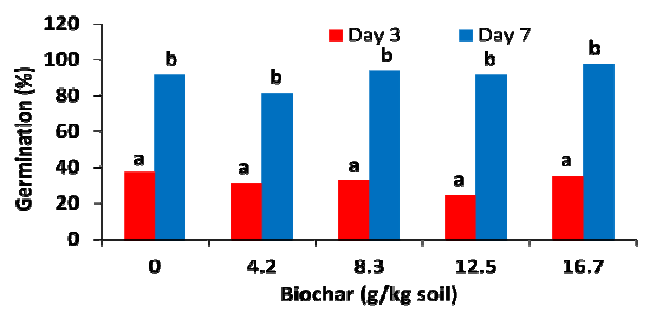

Figure 2. Percentage germination of rice seeds after three and seven days on soil mixed with biochar derived from rice straw. Bars with the same letter are not significantly different $(P<0.05)$.

\subsection{Effect of Maize Stover Biochar on Shoot and Root Lengths of Germinated Maize Seedlings}

Table 1 shows data collected on mean shoot and root lengths of maize seedlings at the end of the germination test on day 7. Except for biochar application rates of $4.2 \mathrm{~g} / \mathrm{kg}$ soil, mean shoot length differed significantly $(p<0.05)$ from the control with increasing rates of biochar application. On the other hand, the control treatment had slightly higher mean root lengths than the biochar treatments. However, the difference between the control and biochar treatments was not significantly different.

Table 1. Mean shoot and root lengths of maize seedlings after seven days germination on a sandy loam soil treated with increasing levels of maize stover biochar

\begin{tabular}{lll}
\hline Biochar (g/kg soil) & Shoot Length $(\mathbf{c m})$ & Root Length $(\mathbf{c m})$ \\
\hline 0.0 & 14.01 & 10.45 \\
4.2 & $16.17 \mathrm{~ns}$ & 10.37 \\
8.3 & $17.79^{*}$ & 11.39 \\
12.5 & $17.56^{*}$ & 10.24 \\
16.7 & $17.38^{*}$ & 8.89 \\
LSD $(0.05)$ & 2.65 & $2.22 \mathrm{~ns}$ \\
\hline
\end{tabular}

ns $=$ not significant $(\mathrm{p}>0.05),{ }^{*}$ significant $(\mathrm{p}<0.05)$ in comparison to the control

\subsection{Effect of rice Stover Biochar on Shoot and Root Lengths of Germinated Maize Seedlings}

Mean shoot and root lengths of rice seedlings at the end of the germination test on day 7 are shown on Table 2. Although the mean lengths of rice shoot on soils treated with biochar were greater than the control, the difference was not significant $(\mathrm{p}<0.05)$. On the other hand, mean root lengths in soils treated with biochar were found to be less than the control but did not differ significantly $(p<0.05)$.

Table 2. Mean shoot and root lengths of rice seedlings after seven days germination on a sandy loam soil treated with increasing levels of rice straw biochar

\begin{tabular}{lll}
\hline Biochar $(\mathbf{g} / \mathbf{k g}$ soil) & Shoot Length $(\mathbf{c m})$ & Root Length $(\mathbf{c m})$ \\
\hline 0.0 & 11.56 & 6.92 \\
4.2 & 12.42 & 6.21 \\
8.3 & 12.10 & 5.74 \\
12.5 & 11.91 & 6.01 \\
16.7 & 12.22 & 6.81 \\
LSD $(0.05)$ & $2.24 \mathrm{~ns}$ & $2.04 \mathrm{~ns}$ \\
\hline
\end{tabular}

$\mathrm{ns}=$ not significant $(\mathrm{p}<0.05)$

\section{Discussion}

Seed germination and emergence is critical to crop growth and development. The presence of inhibitory substances [15] can affect germination and emergence and hence plant growth. Some biochars have been shown to contain phytotoxic substances such as dioxins, furans, polyaromatic hydrocarbons, phenolic compounds as well as heavy metals that can harm soil microorganisms, plants and even humans [16].

In this study, percent germination of maize and rice seeds generally increased slightly above the control at higher biochar application rates although the increase was not signififcant. This study revealed that application of maize stover biochar or rice straw biochar did not have any negative impact on the germination and emergence of maize or rice seeds respectively. Other report on related studies [17] have found no significant difference among different biochars (including maize stover biochar) on the germination of maize seeds. Also, biochar application has been reported to enhanced germination of wheat, clover and mung bean seeds [18]. Other studies on forest seed germination showed that biochar enhances seed germination [19].

The study also revealed that after seven days of emergence there was a significant increase in maize shoot length beyond biochar application rates of $4.2 \mathrm{~g} / \mathrm{kg}$ soil. Thus maize stover biochar enhanced seedling emergence at the very early seedling growth (one week). On the other hand, application of rice straw biochar showed no significant difference in shoot length.

Mean root lengths for both maize and rice plants were were found to generally decrease with biochar applications. Thus, whereas there was a significant difference in maize shoot length between the control and biochar treatments, rice shoot length and root length did not differ significantly among treatments. 


\section{Conclusion}

This study has shown that application of biochar derived from maize stover or rice straw to soil has no adverse effect on the germination and seedling emergence of maize or rice seeds respectively. Unlike rice straw biochar, application of maize stover biochar significantly improved maize seedling emergence relative the control.

The study also demonstrated the relevance of conducting seed germination test using a soil-based assay, particularly with soil from the site to which field applications of biochar are to be made in order to ensure good seedling emergence and crop growth. This study may also have relevance to horticulture where biochar may be used for the establishment of nurseries.

\section{Acknowledgements}

The authors wish to express their gratitude to the field technicians Joseph S. Domingo and Luseni Jaward, and the laboratory technician Samuel Jaia all of the Department of Soil Science Njala University, Sierra Leone for their assistance in soil sample collection and preparation. We would also like to thank Mr. Tamba in the Agricultural Engineering Department for his assistance in the production of biochar. Special thanks also to Mr. Prince Norman of the Sierra Leone Agricultural Institute (SLARI) for helping in the statistical analysis of rice data.

\section{References}

[1] P. M. Fearnside. Global warming and tropical land-use change: greenhouse gas emissions from biomass burning, decomposition and soils in forest conversion, shifting cultivation and secondary vegetation. Climatic Change 46:115-158, 2000.

[2] J. Lehmann, C. Czimczik, D. Laird, and S. Sohi. Stability of biochar in the soil. In: Biochar for Environmental Management Science and Technology (Eds. J. Lehmann, \& S. Joseph), Earthscan Publishers Ltd. 2009.

[3] K. Y. Chan, B. L. Van Zwieten, I. Meszaros, D. Downie, D. and S. Joseph. Using poultry litter biochars as soil amendments. Australian Journal of Soil Research, 46, 437- 444, 2008.

[4] A. Masulili, W. H. Utomo, and Syekhfani. Rice husk biochar for rice based cropping system in acid soil 1. The characteristics of rice husk biochar and its influence on the properties of acid sulfate soils and rice growth in West Kalimantan, Indonesia. Journal of Agriculture Science, 3, 25-33, 2010.

[5] A. Nigussie, E. Kissi, M. Misganaw and G. Ambaw. Effect of Biochar Application on Soil Properties and Nutrient Uptake of Lettuces (Lactuca sativa) Grown in Chromium Polluted Soils. American-Eurasian Journal of Agriculture and Environmental Science, 12 (3), 369-376, 2012

[6] B. Glaser, J. Lehmann and W. Zech. Ameliorating physical and chemical properties of highly weathered soils in the tropics with charcoal: A Review. Biology and Fertility of Soils, 35, 219-230, 2002.

[7] J. Lehman, J. P. Da Silva Jr, C. Steiner, T. Nehls, W. Zech and B Glaser. Nutrient availability and leaching in an archaeological Anthrosol and a Ferralsol of the Central Amazon basin: fertilizer, manure and charcoal amendments. Plant and Soil, 249, 343-357, 2003.

[8] J. Laine, S. Simoni and R. Calles. 1991. Preparation of activated carbon from coconut shell in a small scale concurrent flow rotary kiln. Chem. Eng. Commun. 99:15-23.

[9] K.Y. Chan,. and Z. Xu. Biochar: Nutrient Properties and Their Enhancement. In: J. Lehmann and S. Joseph (eds.). Biochar for Environmental Management: Science and Technology. Earthscan, London, pp.53-66, 2009.

[10] D. Granatstein, C. Kruger, H.P. Collins, M. Garcia-Perez, and J. Yoder. Use of biochar from the pyrolysis of waste organic material as a soil amendment. Center for Sustaining Agric. Nat. Res. 2009. Washington State University, Wenatchee, WA. WSDA Interagency Agreement. C0800248. (http://www.ecy.wa.gov/pubs/0907062.pdf).

[11] D. A. Laird, R.. Brown, J.E. Amonette, and J. Lehmann. 2009. Review of the pyrolysis platform for coproducing bio-oil and biochar. Biofuels, Bioprod. Bioref., 3:547-562.

[12] C. A. Mullen, A. A. Boateng, N. Goldberg, I. M. Lima, D. A. Laird, and K.B. Hicks. Bio-oil and biochar production from corn cobs and stover by fast pyrolysis. Biomass Bioenergy, 34:67-74, 2010.

[13] G. K. Roberts, B. A. Gloy, S. Joseph, N. R. Scott, and J. Lehmann. Life cycle assessment of biochar system: estimating the enegetic, economic, and climate change potential. Environ. Sci. Technol. 44:827-833, 2010.

[14] K. Jones, A. Stewart. Dioxins and furans in sewerage sludges: a review of their occurrence and sources in sludge and of their environmental fate, behaviour, and significance in sludge-amended agricultural systems. Critical Reviews in Environmental Science and Technology /27: 1-85, 1997.

[15] A.I. Piotrowicz-Cieslak, B. Adomas, D.J. Michal-Czyk. Different glyphospate phytotoxicity to seeds and seedlings of selected plant species. Pol. J. Environ. Stud. 19 (1), 123, 2010

[16] X.D. Cao, L.N. Ma, B. Gao, W. Harris. 2009. Dairy-Manure Derived Biochar Effectively Sorbs Lead and Atrazine. Environmental Science \& Technology 43, 3285-3291.

[17] H. F. Free, C. R. McGill, J. S. Rowarth, M. J. Hedley. The effect of biochars on maize (Zea mays) germination', New Zealand Journal of Agricultural Research, 53: 1, 1-4, 2010.

[18] Z. M. Solaiman, D. V. Murphy, L. K. Abbott. 2012. Biochars influence seed germination and early growth of seedlings. Plant and Soil, 353 (1-2), 273-287.

[19] S.J. Robertson, P.M. Rutherford, J.C. López-Gutiérrez, H.B. Massicotte. Biochar enhances seedling growth and alters root symbioses and properties of sub-boreal forest soils. Canadian Journal of Soil Science. 92(2):329-340, 2012. 10.4141/cjss2011-066. 